\title{
Effects of Underwriting and Claims Management on Performance of Property and Casualty Insurance Companies in East Africa
}

\author{
Caren B. Angima, MBA, PhD Candidate
}

Lecturer, University of Nairobi, School of Business

Department of Business Administration, Nairobi, Kenya

\section{Mirie Mwangi, PhD}

Senior Lecturer, University of Nairobi, School of Business

Department of Finance and Accounting, Nairobi, Kenya

\section{doi: 10.19044/esj.2017.v13n13p358 URL:http://dx.doi.org/10.19044/esj.2017.v13n13p358}

\begin{abstract}
The insurance sector plays an important role in service economy of any country by underwriting of risks inherent in most sectors thus providing a sense of peace to most economic entities. Performance of general insurance companies is expected to be related to various factors, including optimal underwriting and prompt and efficient claims management functions. This study investigated the effect of underwriting and claims management practices on the performance of general insurance firms in East Africa. The study employed multiple linear regression analysis using primary and secondary data collected from 82 general insurers in Kenya, Uganda and Tanzania. The findings show that there is a significant positive relationship between underwriting and claims management practices employed by the firms and non-financial performance, but the relationship with financial performance was insignificant. The implication is that a profit oriented insurance firm should embrace a claims function that is closely related with the underwriting and pricing of the firm's portfolio for meaningful results. It is recommended that general insurance companies focus on other important factors besides underwriting and claims management order to improve overall financial performance.
\end{abstract}

Keywords:Underwriting, Claims Management, Performance, Property and Casualty insurance Firms

\section{Introduction}

Insurance companies are important in the role they play in most countries as they contribute to efficient resource allocation through 
management of risks in almost all sectors of any economy. Underwriting of these risks lessens the burden and creates stability for most entities enabling them concentrate in their core activities thus contributing to economic development. In order to meet their obligations, insurers must have in place a prompt and efficient claims management (Duompos et al., 2012; Udaibir et al., 2003). Good performance of the insurance sector therefore contributes to the overall prosperity of an economy. Underwriting involves risk measurement and evaluation leading to determination of the commensurate cost to cover that risk. (Dowd et al., 2007) while an insurance claim consist of a benefit paid to the insured person for a loss that may be covered under the insurance contract. (IRA-U, 2014). The claims management phase gives an opportune moment for delivery by the insurers and to favourably impress the policyholder and enhance their reputation for better performance (Bates and Atkins (2007). The Insurance industry in East Africa is dominated by general insurance in terms of gross premiums written and the performance of these insurers is therefore of paramount importance to development of the sector (IRA, 2014).

Underwriting is done by grouping together similar risks for rating and the resultant rates are adjusted to take into account the group experience. This is then adjusted to cater for inflation, uncertainty and expenses. Stochastic models and sophisticated regression analysis and data mining tools are used by actuaries to take into account severity and frequency of claims in order to sufficiently price the risk (Baranoff et al., 2009; Dowd et al., 2007; Promislow, 2011). Claim costs constitute a large proportion of an insurer's expenses and according to Barth and Eckles (2009), claims erode earnings and, its costs highly influence the profitability of Property and Casualty (P \& C) insurers. Therefore, correctly assessed and fair claims administration practices that are in line with optimal underwriting policies play a key role in enhancing better performance of $\mathrm{P} \& \mathrm{C}$ insurers (Wilkinson, 2008).

An insurer's total claims may be affected by various factors including underestimated liabilities from unpaid (expired) past policies or underpriced current business, incorrect or inaccurate underwriting, wrong or inaccurate assumptions on the frequency and severity of losses or from factors wholly beyond the underwriter's control. In addition, it may be that much of the total written premiums remain outstanding for long periods and turns out to be uncollectible (Shiu, 2004). For a P \& C insurer, the ratio of claims to premiums (loss ratio) partly represents underwriting results and denotes the quality of business underwritten and is an important indicator of whether the pricing policy of the firm is correct. Loss ratio is at the centre of key claims management efforts of an insurer and is therefore very vital for the long term profitability of the firm (Yusuf \& Dansu, 2012). 
Performance is a general measure of a firm's actual output or results as assessed against its intended outputs and is thus related to its overall health over a given period of time and may be looked at from various perspectives (Kaplan and Norton, 1996). The indicators are financial performance (FP), which includes overall profitability (indicated by ratios such as return on investment, return on sales, return on assets, and return on equity), and profit margin (Almajali et al., 2012; Ross et al., 2009; Zender, 2004). Insurer profitability consists of the excess of revenues over costs incurred in underwriting the business and is part of overall financial management which partly contributes to maximization of owner's wealth. Non-financial parameters some of which may be difficult to quantify, include operational performance, efficiency and overall effectiveness including improved market share, quality of service, innovation and reputation which contribute to better overall performance in comparison with competitors (Lewin \& Minton, 1986). There is therefore need to consider both quantitative and qualitative indicators in order to arrive at a suitable measure of overall financial soundness of a firm (Udaibir, et.al, 2003)

\section{Literature Review}

Sound underwriting guidelines are critical to an insurance company's performance including optimal correct measurement of risk exposures and appropriately pricing them for cover. Most companies will target acceptance of a large majority of risks at standard rates, but still impose modified premium that take into account loss experience and other factors for risks not meeting standard norms (Santomero \& Babble, 1997). Selective underwriting may cut costs leading to improved profitability but market share may be lost to competitors (Barth and Eckles, 2009). Lowering of underwriting standards by reducing prices may result in higher claim costs which in turn may lead to shrinking/poor underwriting results (Harrington \& Danzon, 1990). The underwriting strategy and claims management program of an insurer are related in that if more of the insurance products which are sold lead to moral hazard, adverse selection and high outstanding premiums, this will lead to high claims and a negative relationship with both the underwriting profit and the total net profit (D’Arcy \& Gorvett, 2004).

Claim expenses constitute the largest cost of an insurer hence the need for insurers to take their claim handling functions seriously. (Harrington \& Niehaus, 2006; Bates \& Atkins, 2007; SAS, 2012). An effective claims management program encompasses prevention of losses by taking precautionary measures as a key element in reducing risks and also a key driver of profitability (Fernandez, 2009). A good claims management 
program should be proactive in dealing with genuine claims, maximizing on recovery opportunities from salvage, subrogation and third parties, reporting regularly, minimizing unnecessary costs and reducing loss adjustment expenses (Productivity Commission, 2002). It also includes handling claims expeditiously, reviewing of costs associated with litigation, and monitoring expenses and, future payments plans in order to reduce on disputes and delays so as to reduce the insurer's expense (SAS, 2012; Calandro \& O’Brien, 2004; Leverty \& Grace, 2012; Baranoff et al., 2000. Qaiser (2013) notes that claims management also involves giving good service to claimants, who should be treated courteously. This will result in higher customer satisfaction, retention and policy renewals that are fundamental to profit and better financial performance. Poor handling of claims may lead to lose of confidence by policyholders leading to damaged reputation and poor performance (Banjo, 1995; Butler \& Francis, 2010).

Optimal claims management practices also include accurately assessing the reserves associated with each claim as they represent liabilities and future financial obligations for the insurer. (Baranoff et al., 2009). Financially and legally, an insurer is expected to maintain a certain level of reserves to hedge against their unearned premiums. As premiums grow, so do the required reserves (Calandro \& O’Brien, 2004). The company therefore must estimate its future payments before it can determine losses, including an estimation of the payments for claims that have been incurred but not yet reported (IBNR) (Leverty \& Grace, 2012). This calls for development and availability of skills in loss reserving and claim projection, together with optimal reinsurance arrangements that reduce the need for contingent increases of loss reserve (Baranoff et al., 2009).

Profit improves the insurer's solvency state and also plays a vital role in persuading stakeholders to fund the business (Chen \& Wong, 2004). Low profitability may signal fundamental problems of the insurer and may be considered a leading indicator for solvency problems. Failure of a P \& C Insurer may partly likely be due to a weak underwriting and claims management programs (Udaibir et al., 2003). Such a situation could lead to huge losses due to disruption in business operations and high costs incurred to mitigate the risks ( Tahir \& Razali, 2011). According to Venkatraman and Ramanujams (1986), operational performance focuses on non financial measures and concentrates on factors that may subsequently lead to financial performance. These include product- market outcomes (for example market share, efficiency, new product introduction and innovation, and product or service quality, post sales service) and internal process outcomes (productivity, employee retention and satisfaction, and cycle time among others). Kaplan and Norton (1996) also include the learning and growth perspective which includes measurements for people including employee 
satisfaction, acquisition, retention, training, skills, and morale with systems measures including innovative activities and availability of critical real time information needed for front line employees.

A number of studies in this area include a cross-sectional study by Yusuf and Dansu (2012) on the effect of claim cost on Nigeria's non-life insurers' profitability which established that strategic claims management will aid the profitability of the firm through reasonable cost control, suitable key staff and developing an analytical framework to detect and reduce excesses in order to enhance performance. Malik (2011) studied the Pakistan's insurance market to determine determinants of profitability, using return on assets (ROA) with findings that loss ratio negatively impacted on the insurers' profitability. Kim et al., (1995), using a dynamic statistical model to predict failures of U.S. P \& C insurers established that several variables, including loss reserves and reinsurance recoveries were significant. Mehari and Gemiro (2013) in a study of the Ethiopian market confirmed the findings by Malik (2011) and Ahmed et al. (2011) by establishing that good standards of management mitigate exposure to claims and other expenses and increase returns contributing to enhanced performance. Mwangi and Iraya (2014) in their study in Kenya on determinants of financial performance of general insurers established a key finding that there was a negative relationship for loss ratio and FP.

\section{Research Problem}

Insurers are in the business of risk taking and underwrite risky business. Excessive risk-taking may lead to higher insurance losses and subsequently increased management expenses in claims investigation and loss adjustment, litigation, claims payment and claims monitoring costs. These may lead to a decline in reported operational performance. On the other hand, selective underwriting and optimal management of the claims function may lead to lower losses and expenses that may in turns to lead to enhanced performance. There is therefore need to ensure that optimal underwriting and claims management standards are applied to mitigate insurers' exposure to underwriting losses for enhanced performance.

A number of empirical studies have been carried out in various countries to explore the relationship between various firm specific factors and financial performance of general insurance companies (Mwangi \& Iraya (2014), Shiu (2004), Chen \& Wong (2004), Kim et al. (1995) and Adams \& Buckle (2003). The cost of claims is one of the main factors that influence the profitability of insurance companies but few studies have concentrated on the effect of underwriting claims management practices on the performance of $\mathrm{P} \& \mathrm{C}$ insurers, especially in the context of developing countries. This necessitates a study of this nature especially in the East African region. The 
study hypothesizes that underwriting and claims management practices are significantly related to performance of P \& C insurance firms in East Africa.

\section{Data and Methodology}

The study adopted a descriptive research design and was carried out in three East African countries' insurance industries (Kenya, Uganda and Tanzania) targeting all the 82 P \& C firms as at December, 2015. Primary data on underwriting, claims management practices and non-financial performance was collected from the Underwriting and Claims Managers of these companies while secondary data was obtained from the yearly financial reports of the insurance companies for the period 2010-2014. The data generated for this study include Net Income Before Tax (NIBT) and total assets which were used to calculate Return on Asset (ROA) as a measure of financial performance.

In this study, the dependent variable is Financial Performance represented by (ROA), and Non-Financial Performance represented by measures for innovation, service quality, and reputation. The independent variable is underwriting practices and claim management practices, represented by the composite scores for the likert type questions that were administered to the respondents. The variables were measured on a 5-point Likert scale whereby respondents were expected to either: "strongly agree", "agree”, "be neutral”, “disagree” or "strongly disagree”. For each question, the response that represented the most favorable response for the practices was accorded 5 points, followed by 4, 3, 2, and 1 for the least favorable respectively. The same rating was adopted for non-financial performance viz: “excellent performance”(5), “good performance” (4), “average performance”(3), “poor performance”(2) or "very poor performance” (1) in respect of the various aspects. follows:

The linear regression models developed for this study were as

$\mathrm{FP}=\alpha+\beta_{1}(\mathrm{UW})+\beta_{2}(\mathrm{CM})+\mathrm{e}$

$\mathrm{NFP}=\alpha+\beta_{1}(\mathrm{UW})+\beta_{2}(\mathrm{CM})+\mathrm{e}$

Where:

ROA)

$\mathrm{FP}=$ Financial performance of insurance firms (represented by

NFP $=$ Non-Financial Performance of insurance firms (represented by quality of service, innovation and reputation composite score)

UW= Underwriting Score

$\mathrm{CM}=$ Claims management Score

$\alpha=$ Intercept, a sample-wide constant

$\beta_{1}, \beta_{2}=$ coefficient for the respective determinant 
Data on underwriting and claims management practices was analyzed using descriptive statistics of mean and standard deviation while regression analysis was employed in establishing the relationship between the variables

\section{Results and Discussion}

The data was gathered from 57 out of the 82 firms on the variables of interest representing a response rate was 69.5\%. Table 1 and 2 provide a summary of the descriptive statistics (with details in the appendix) which show that on average, the respondent firms agreed that there is optimal application of the underwriting and claims management practices by the respective firms. The non financial scores details (details in appendix) results also indicate that the firms have performed well in reputation and service quality but average on innovation. The linear regression results are shown in Table 3.

Table 1: Summary of Mean Scores for Underwriting and Claims Management Practices

\begin{tabular}{|c|r|r|r|r|r|}
\hline Actuarial Risk Management Practice & Mean & \multicolumn{1}{|l|}{ SD } & \multicolumn{1}{l}{$\begin{array}{l}\text { S } \\
\text { K }\end{array}$} & \multicolumn{1}{l|}{$\begin{array}{l}\text { U } \\
\text { U }\end{array}$} \\
\hline Underwriting Practices & 3.88 & .483 & -.403 & -.693 & 0.13 \\
\hline Claims management Practices & 3.98 & .378 & -.780 & -.384 & 0.10 \\
\hline
\end{tabular}

$N=57: S D$ is standard deviation, $S K$ is skewness, $K U$ is kurtosis $C V$ is coefficient of variation.

Source: Research Data

Table 2: Summary: Non-Financial Performance

\begin{tabular}{|c|l|l|l|l|l|}
\hline Performance Indicator & Mean & SD & SK & KU & CV \\
\hline $\begin{array}{c}\text { Financial Performance } \\
\text { (ROA) }\end{array}$ & 5.98 & 9.057 & - & 3.126 & 1.51 \\
\hline $\begin{array}{c}\text { Non-financial } \\
\begin{array}{c}\text { performance(Innovation, } \\
\text { reputation, Service } \\
\text { quality) }\end{array}\end{array}$ & & .421 & .772 & .936 & \\
\hline
\end{tabular}

$N=57: S D$ is standard deviation, $S K$ is skewness, $K U$ is kurtosis $C V$ is coefficient of variation

Table 3: Regression Results for Financial Performance as Dependent Variable and Underwriting and Claims Management practices as Predictors

a) Model Summary

\begin{tabular}{ccccc}
\hline Model & $\mathrm{R}$ & $\begin{array}{c}\mathrm{R} \\
\text { Square }\end{array}$ & $\begin{array}{c}\text { Adjusted } \\
\text { R square }\end{array}$ & $\begin{array}{c}\text { Standard } \\
\text { error of } \\
\text { the } \\
\text { estimate }\end{array}$ \\
\hline 1 & $.199^{\mathrm{a}}$ & .040 & -.004 & 13.940
\end{tabular}

a. Predictors: (Constant), Claims management practices, Underwriting practices 
b) Goodness of Fit- ANOVA

\begin{tabular}{|c|c|c|c|c|c|c|}
\hline $\begin{array}{l}\text { Mo } \\
\text { del }\end{array}$ & & $\begin{array}{l}\text { Sum } \\
\text { of } \\
\text { squar } \\
\text { es }\end{array}$ & $\begin{array}{l}\mathrm{d} \\
\mathrm{f}\end{array}$ & $\begin{array}{c}\text { Mean } \\
\text { squar } \\
\text { e }\end{array}$ & $\mathrm{F}$ & $\begin{array}{l}\text { S } \\
\text { i } \\
\text { g }\end{array}$ \\
\hline 1 & $\begin{array}{c}\text { Regr } \\
\text { essio } \\
n\end{array}$ & 353.957 & 2 & 176.978 & $\begin{array}{l}. \\
9 \\
1 \\
1\end{array}$ & $\begin{array}{l}\cdot \\
4 \\
1 \\
0 \\
\mathrm{~b}\end{array}$ \\
\hline & $\begin{array}{c}\text { Resi } \\
\text { dual } \\
\text { Total } \\
\end{array}$ & $\begin{array}{l}8549.922 \\
8903.878 \\
\end{array}$ & $\begin{array}{l}44 \\
46 \\
\end{array}$ & 194.316 & & \\
\hline
\end{tabular}

a. Dependent Variable: Financial Performance

b. Predictors: (Constant), Claims management practices, underwriting practices

c) Regression coefficients ${ }^{\mathrm{a}}$

\begin{tabular}{|c|c|c|c|c|c|}
\hline \multirow[t]{2}{*}{ Model } & & B & $\begin{array}{l}\text { Std } \\
\text { error }\end{array}$ & \multicolumn{2}{|c|}{ Sig. } \\
\hline & Constant & -7.835 & 24.424 & -.321 & .750 \\
\hline & $\begin{array}{c}\text { Underwriting } \\
\text { practices } \\
\text { Claims }\end{array}$ & -3.117 & 4.894 & -.637 & .528 \\
\hline & $\begin{array}{l}\text { management } \\
\text { practices }\end{array}$ & 7.006 & 5.303 & 1.321 & .193 \\
\hline
\end{tabular}

a. Dependent Variable: Financial Performance

The results of standard linear regression model with financial performance as the dependent variable and underwriting and claims management practices as predictors are reported in Table 3(a-c) for model summary, goodness of fit and coefficients respectively. The model reveals a statistically insignificant relationship ( $\mathrm{P}>.05)$ between financial performance and underwriting and claims management practices with Adjusted $\mathrm{R}^{2}=$ $.004, \mathrm{~F}(2,44)=.911$, and a standard error of 13.940. Underwriting and claims management practices account for $4 \%$ of the variance in financial firm performance. The model coefficients are shown in Table 3(c) with both underwriting ( $\beta=-3.117), p>0.05)$ and claims management practices $(\beta=$ 7.006, $\mathrm{p}>0.05$ ) being insignificant predictors of firm financial performance. This may be due to the fact that there are many other variables that affect financial performance of an insurance firm which were not considered in this study. 
Table 4: Regression Results for Non-Financial Performance as Dependent Variable and Underwriting and Claims Management practices as Predictors

a) Model Summary

\begin{tabular}{ccccc}
\hline Model & $\mathrm{R}$ & $\begin{array}{c}\mathrm{R} \\
\text { Square }\end{array}$ & $\begin{array}{c}\text { Adjusted } \\
\text { R square }\end{array}$ & $\begin{array}{c}\text { Standard } \\
\text { error of } \\
\text { the } \\
\text { estimate }\end{array}$ \\
\hline 1 & $543^{\mathrm{a}}$ & .295 & .266 & .364 \\
\hline
\end{tabular}

a. Predictors: (Constant), Claims management practices, Underwriting practices b) Goodness of Fit- ANOVA

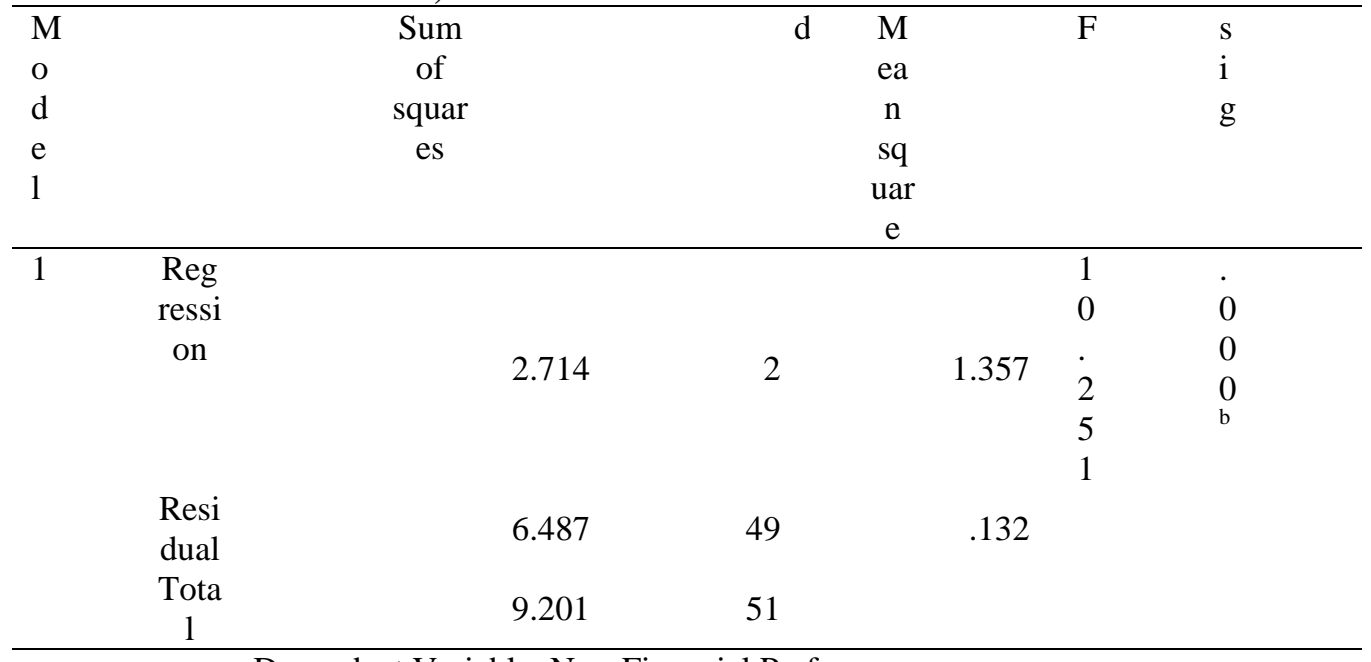

a. Dependent Variable: Non-Financial Performance

b. Predictors: (Constant), Claims management practices, underwriting practices

c) Regression coefficients ${ }^{\mathbf{a}}$

\begin{tabular}{|c|c|c|c|c|c|}
\hline Model & & B & $\begin{array}{l}\text { Std } \\
\text { error }\end{array}$ & \multicolumn{2}{|c|}{ Sig. } \\
\hline & Constant & 1.071 & .610 & 1.754 & .086 \\
\hline & $\begin{array}{l}\text { Underwriting } \\
\text { practices }\end{array}$ & .285 & .114 & 2.498 & .016 \\
\hline & $\begin{array}{c}\text { Claims } \\
\text { management } \\
\text { practices }\end{array}$ & .411 & .137 & 2.986 & .004 \\
\hline
\end{tabular}

a. Dependent Variable: Non-Financial Performance

The results of standard linear regression model with non-financial performance as the dependent variable and underwriting and claims management practices as predictors are reported in Table 4(a-c) for model summary, goodness of fit and coefficients respectively. The model reveals a statistically significant relationship $(\mathrm{P}<.05)$ between non financial performance and underwriting and claims management practices with Adjusted $\mathrm{R}^{2}=.266, \mathrm{~F}(2,49)=10.251$, and a standard error of .364 . 
Underwriting and claims management practices account for $29.5 \%$ of the variance in non financial firm performance. Model coefficients in table 4(c) show both underwriting $(\beta=.285), \mathrm{p}<0.05)$ and claims management practices $(\beta=-411, \mathrm{p}<0.05)$ as significant predictors of non financial firm performance.

The analytical model is thus specified as: $\mathrm{NFP}=1.071+.285 \mathrm{UW}$ $+.411 \mathrm{CM}$

\section{Conclusion}

The relationship between financial performance and underwriting and claims management practices was not significant as theoretically expected. This may be due to the fact that there are many other variables that affect financial performance of an insurance firm which were not considered in this study. The relationship between non financial performance and underwriting and claims management practices was positive and significant as hypothesized. This means that a profit oriented insurance firm must therefore embrace a claims function that is closely related with the underwriting and pricing of the firm's portfolio for meaningful results. The findings will help P \& C firms in the region to focus more on their risk assessment and claims management programs and adopt models that will enhance their performance. Although not comparable directly due to the different variables studied, this finding confirms that of Yusuf and Dansu (2012) for Nigerian general insurance companies on the contribution of claims expenses on the profitability of general insurance companies and Kim et al, (1998) for the U.S. market. .

The model used in the study focused only on underwriting and claims management practices as a determinant of firm performance of $\mathrm{P}$ \& $\mathrm{C}$ insurance firms in East Africa. However, there are other insurance risk management practices like pricing and reinsurance as well as other factors such as liquidity, leverage, investment income among others, which may have an influence on performance which were not considered and the inclusion of these variables in future studies would make the findings more robust.

\section{References:}

1. Adams, M. \& Buckle, M. (2003). The determinants of corporate financial performance in the Bermuda insurance market. Applied Financial Economics, 13(2), 33-43.

2. Ahmed, N., Ahmed, Z. \& Usman, A. (2011). Determinants of performance: A case of life insurance sector of Pakistan. International Research Journal of Finance and Economics, 61, 123128 
3. Almajali, A. Y., Alamro, S. A. \& Al-Soub, Y. Z. (2012). Factors affecting the financial performance of Jordanian insurance companies listed at Amman Stock Exchange. Journal of Management Research, 4(2), 266-289

4. Banjo, K. (1995) Principles and Practice of Insurance. Lagos: Dekinban Ventures Publishers Ltd.

5. Baranoff, E. G. Sager,T. \& Shively, T. (2009). Semi-parametric modeling as a managerial tool for solvency. Journal of Risk and Insurance, 67(3), 369-396

6. Barth, M. M. \& Eckles, D. L. (2009). An empirical investigation on the effect of growth on short term changes in loss ratios. Journal of Risk and Insurance, 76(4), 867-885

7. Bates, I. \& Atkins, D. (2007) Risk, Regulation, and Capital Adequacy. CIIN study course A510

8. Butler, S. \& Francis, P. (2010). Cutting the cost of Insurance Claims: taking Control of the process. Booz and Company.

9. Chen, R. \& Wong, K. A. (2004). The determinants of financial health of Asian insurance companies. The Journal of Risk and Insurance, 71(3), 469-499.

10. Calandro, J. J. \& O’Brien, T. (2004). A user friendly introduction to property-casualty claim reserves. Risk Management and Insurance Review, 7(2), 177-187

11. D’Arcy, S. \& Gorvett, R. (2004). The use of dynamic financial analysis to determine whether an optimal growth rate exists for a Property-Liability insurer, Journal of Risk and Insurance, 71: 583615

12. Dowd, K., Bartlett, D. L., Chaplin, M., Kelliher, P. \& O’Brien, C. (2007). Risk Management In The UK Insurance Industry: The Changing State of Practice. Centre for Risk \& Insurance Studies, University of Nottingham

13. Duompos, M., Gaganis, C. \& Pasiouras, F. (2012). Estimating and explaining the financial performance of Property and Casualty Insurers: A two stage analysis. The Business and Economics Research Journal, 5(2), 155-170

14. Fernández, C. (2009). Risk Management in the Insurance Business Sector, Everis MFC Artes Gráficas, S.L.

15. Harrington, S. E. \& Danzon, E. (1990). Price cutting in liability insurance markets, working paper, Department of Insurance and Risk Management.

16. The Wharton School, University of Pennsylvania

17. Harrington, S.E. \& Niehaus, G.R. (2006) Risk Management and Insurance. U.S.A., New York: Mc Graw- Hill. 
18. IRA -U. (2014). Uganda Insurance industry Annual Report, available at ira.go.ug

19. Kaplan, R. S. \& Norton, D. P. (1996). The Balanced Scorecard: Translating Strategy into Action.: Harvard Business School Press, Boston

20. Leverty, J. T. \& Grace, M. F. (2012). Property-Liability insurer reserve error: motive, manipulation, or mistake. The Journal of Risk and Insurance, 79(2), 351-380

21. Lewin, A. Y. \& Minton J. W. (1986). Determining Organizational Effectiveness: Another look, and an agenda for research, Management Science, 32(5),514-538.

22. Malik, H. (2011) Determinants of Insurance Companies Profitability: An Analysis of Insurance Sector of Pakistan. Academic Research International, 1(3), 315-321

23. Mehari, D. \& Aemiro, T. (2013). Firm specific factors that determine insurance companies' performance in Ethiopia, European Scientific Journal, 9(10), 245-255

24. Mwangi, M. \& Iraya, C. (2014). Determinants of financial performance of general insurance underwriters in Kenya. Journal of Business and Social Science, 5(3), 210-215.

25. Productivity Commission. (2002). Public Liability Claims Management. Research Report, Canberra.

26. Promislow, S. D. (2011). Fundamentals of Actuarial Mathematics, $2^{\text {nd }}$ edition, John Wiley and Sons Ltd, UK.

27. Qaiser, R. (2013). Claims Management in General Insurance - Issues \& Concerns. National Insurance Academy, Pune Univeristy, India

28. Ross, S. A., Westerfield, R. W., Jaffe, J. \& Jordan, B. D. (2009). Modern Financial Management. 8th Edition. McGraw-Hill.

29. Santomero, A.M. \& Babbel, D. F. J. (1997). Financial risk management by insurers: An analysis of the process, Journal of Risk and Insurance, 64 (2), 231-270

30. SAS (2012) predictive claims processing: transforming the insurance claims lifecycle using analytics. A white paper by SAS Institute Inc. available@/www.sas.com

31. Standard \& Poor's. (2005). Enterprise Risk Management For Financial Institutions: Rating Criteria And Best Practice The McGraw-Hill Companies, Inc. NY

32. Shiu, Y. (2004). Determinants of United Kingdom general insurance company performance. British Actuarial Journal, 10(5), 1079-1110.

33. Tahir, I. M. \& Rizali, A. R. (2011). The relationship between enterprise risk management and firm value: Evidence from 
Malaysian Public Listed Companies, International Journal of Economics and Management sciences, 1(2), 32-41

34. Udaibir, S., Das, N. D. \& RiPodpiera, R. (2003). Insurance and Issues in Financial Soundness. IMF Working Paper

35. Venkatraman, N. \& Ramanujam V. (1986). Measurement of Business Performance in Strategy Research: A comparison of approaches, Academy of Management Review,11(4), 801-814.

36. Wilkinson, C. (2008). Catastrophe modeling: A vital tool in the risk management. Insurance. Information Institute Inc, Newyork

37. Yusuf, T. O \& Dansu, F. S. (2012). The effect of claim cost on insurers' profitability in Nigeria. International Journal of Business and Commerce, 3(10), 1-20

38. Zender, J. F. (2004). Evaluating Financial Performance, Leeds School of Business

Underwriting Practices

\section{Appendix}

\begin{tabular}{|c|c|c|c|c|c|}
\hline Underwriting Practices & $\begin{array}{l}\mathbf{M} \\
\mathbf{e} \\
\mathbf{a} \\
\mathbf{n}\end{array}$ & $\begin{array}{l}\text { S } \\
\text { D }\end{array}$ & $\begin{array}{l}\mathbf{K} \\
\mathbf{U}\end{array}$ & $\begin{array}{l}\mathbf{S} \\
\mathbf{K}\end{array}$ & $\mathbf{C V}$ \\
\hline $\begin{array}{l}\text { Risk exposures measures } \\
\text { determines premiums }\end{array}$ & 4.40 & .728 & 2.395 & -1.375 & 0.17 \\
\hline $\begin{array}{l}\text { firm concentrates on risks with } \\
\text { competitive advantage }\end{array}$ & 3.68 & 1.167 & -.357 & -.674 & 0.32 \\
\hline Selective on business taken up & 3.70 & 1.117 & .113 & -.887 & 0.30 \\
\hline $\begin{array}{l}\text { Business that increases risks is } \\
\text { avoided }\end{array}$ & 3.98 & 1.087 & .657 & $\begin{array}{r}- \\
1.109 \\
\end{array}$ & 0.27 \\
\hline $\begin{array}{l}\text { Use Claim frequency and } \\
\text { severity assessing and pricing } \\
\text { risks }\end{array}$ & 4.35 & .612 & -.616 & -.367 & 0.14 \\
\hline $\begin{array}{l}\text { Use coinsurance and } \\
\text { reinsurance for risky business }\end{array}$ & 4.09 & 1.243 & .486 & 1.212 & 0.30 \\
\hline $\begin{array}{l}\text { Concentrate on risks which } \\
\text { make profits }\end{array}$ & 3.21 & 1.048 & -.587 & -.247 & 0.33 \\
\hline $\begin{array}{l}\text { Use standardized underwriting } \\
\text { processes }\end{array}$ & 3.56 & .945 & -.107 & -.578 & 0.27 \\
\hline $\begin{array}{l}\text { Considers competition in } \\
\text { underwriting process }\end{array}$ & 4.04 & .934 & 1.501 & $\begin{array}{r}- \\
1.185\end{array}$ & 0.23 \\
\hline $\begin{array}{l}\text { marketing of substandard } \\
\text { business discouraged }\end{array}$ & 3.37 & 1.175 & -.462 & -.357 & 0.35 \\
\hline
\end{tabular}




\begin{tabular}{|l|r|r|r|r|r|}
\hline $\begin{array}{l}\text { Risk management models used } \\
\text { to asses catastrophic events }\end{array}$ & 3.65 & 1.077 & -.731 & -.402 & 0.30 \\
\hline $\begin{array}{l}\text { Adverse selection handled } \\
\text { using various approaches }\end{array}$ & 4.21 & .655 & 1.977 & $\begin{array}{r}- \\
1.068\end{array}$ & 0.16 \\
\hline Mean Score & $\mathbf{3 . 8 8}$ & $\mathbf{. 4 8 3}$ & $\mathbf{- . 6 9 3}$ & $-\mathbf{- . 4 0 3}$ & $\mathbf{0 . 1 3}$ \\
\hline
\end{tabular}

$N=57: S D$ is standard deviation, $S K$ is skewness, $K U$ is kurtosis $C V$ is coefficient of variation,

Source: Research Data

Claims Management Practices

\begin{tabular}{|c|c|c|c|c|c|}
\hline Claims Management Practices & $\begin{array}{l}\mathbf{M} \\
\mathbf{e} \\
\mathbf{a} \\
\mathbf{n}\end{array}$ & $\begin{array}{l}\text { S } \\
\text { D }\end{array}$ & $\begin{array}{l}\mathbf{K} \\
\mathbf{U}\end{array}$ & $\begin{array}{l}\mathbf{S} \\
\mathbf{K}\end{array}$ & $\mathbf{C V}$ \\
\hline $\begin{array}{l}\text { separate and autonomous claims } \\
\text { department }\end{array}$ & 4.04 & 1.101 & .658 & -1.152 & 0.27 \\
\hline $\begin{array}{l}\text { Regularly analysis, reporting and } \\
\text { minimization of unnecessary costs }\end{array}$ & 4.37 & .555 & -.812 & -.101 & 0.13 \\
\hline $\begin{array}{l}\text { Sufficient premiums charged to cover all } \\
\text { company claims and expenses }\end{array}$ & 3.61 & 1.056 & -.583 & -.581 & 0.29 \\
\hline $\begin{array}{l}\text { Correct analysis done resulting in actual } \\
\text { claims being less than projected most of } \\
\text { the time }\end{array}$ & 3.37 & 1.029 & -.483 & -.295 & 0.31 \\
\hline $\begin{array}{l}\text { Loss reserving done for all claims under } \\
\text { all classes underwritten }\end{array}$ & 4.26 & 1.009 & 4.107 & -1.963 & 0.24 \\
\hline $\begin{array}{l}\text { Loss reserving done for long tail lines } \\
\text { only }\end{array}$ & 2.30 & 1.180 & .292 & .944 & 0.51 \\
\hline $\begin{array}{l}\text { several loss control measures are used to } \\
\text { reduce severity of losses }\end{array}$ & 3.72 & 1.031 & .298 & -.822 & 0.28 \\
\hline $\begin{array}{l}\text { Undertake precautionary underwriting } \\
\text { measures for unfamiliar risks }\end{array}$ & 3.80 & 1.052 & .212 & -.757 & 0.28 \\
\hline $\begin{array}{l}\text { Endeavour to avoid protracted legal } \\
\text { disputes in order to reduce claim costs }\end{array}$ & 4.12 & .734 & .965 & -.760 & 0.18 \\
\hline $\begin{array}{l}\text { claims handled expeditiously and valid } \\
\text { claims paid efficiently }\end{array}$ & 4.51 & .630 & 2.904 & -1.365 & 0.14 \\
\hline Courteously deal with claimants & 4.42 & .565 & -.834 & -.293 & 0.13 \\
\hline $\begin{array}{l}\text { Quality customer care leads to improved } \\
\text { claims settlement record for our firm. }\end{array}$ & 4.35 & .582 & -.652 & -.229 & 0.13 \\
\hline $\begin{array}{l}\text { Review claims performance and } \\
\text { monitoring of claims done regularly. }\end{array}$ & 4.46 & .600 & 2.988 & -1.113 & 0.13 \\
\hline $\begin{array}{l}\text { Try and avoid disputes in claims } \\
\text { payment. }\end{array}$ & 4.37 & .723 & 2.271 & -1.283 & 0.17 \\
\hline Mean Score: $\mathbf{N}=57$ & 3.98 & .378 & -.384 & -.780 & .10 \\
\hline
\end{tabular}

$S D$ is standard deviation, $S K$ is skewness, $K U$ is kurtosis CV is coefficient of variation.

Source: Research Data 
Non Financial Firm Performance:

\begin{tabular}{|c|c|c|c|c|c|}
\hline $\begin{array}{c}\text { Firm Performance- } \\
\text { Quality of Service / Market Share }\end{array}$ & $\begin{array}{l}\mathbf{M} \\
\mathbf{e} \\
\mathbf{a} \\
\mathbf{n}\end{array}$ & $\begin{array}{l}\text { S } \\
\text { D }\end{array}$ & $\begin{array}{l}\mathbf{K} \\
\mathbf{U}\end{array}$ & $\begin{array}{l}\mathbf{S} \\
\mathbf{K}\end{array}$ & $\begin{array}{l}\mathrm{C} \\
\mathrm{V}\end{array}$ \\
\hline Firm emphasizes on customer-centre services & 4.53 & .538 & -1.055 & -.464 & 0.12 \\
\hline $\begin{array}{l}\text { Provision of high quality services that equals } \\
\text { customer expectations. }\end{array}$ & 4.14 & .789 & 1.024 & -.935 & 0.19 \\
\hline $\begin{array}{l}\text { Market share has been maintained for } \\
\text { the last } 3 \text { years. }\end{array}$ & 3.96 & .981 & -.573 & -.633 & 0.25 \\
\hline Process claims within a 14 day period.. & 3.72 & .959 & .123 & -.658 & 0.26 \\
\hline $\begin{array}{l}\text { Mechanisms exist to ensure } \\
\text { satisfactory resolving of customer } \\
\text { complaints }\end{array}$ & 4.21 & .590 & 2.497 & -.616 & 0.14 \\
\hline $\begin{array}{l}\text { Quality service enhances referrals } \\
\text { from existing customers }\end{array}$ & 4.19 & .611 & -.392 & -.122 & 0.15 \\
\hline $\begin{array}{l}\text { Quality service has led to general } \\
\text { increase in our client base }\end{array}$ & 4.26 & .791 & .649 & -.961 & 0.19 \\
\hline $\begin{array}{l}\text { Our competitive advantage has led to } \\
\text { firm's improved market share }\end{array}$ & 3.91 & .851 & 1.549 & -.909 & 0.22 \\
\hline $\begin{array}{l}\text { We are able to determine portion of } \\
\text { revenues from new market segments }\end{array}$ & 3.82 & .897 & 1.251 & -1.046 & 0.23 \\
\hline $\begin{array}{l}\text { We are ahead of others in regular development } \\
\text { of new /enhanced products }\end{array}$ & 3.61 & 1.003 & .154 & -.586 & 0.28 \\
\hline \multicolumn{6}{|l|}{$\begin{array}{l}\text { New product development is takes into account } \\
\text { recent events like: }\end{array}$} \\
\hline $\begin{array}{ll} & \text { Terrorism/Flooding } \\
\end{array}$ & 3.82 & 1.011 & .607 & -.831 & 0.26 \\
\hline - $\quad$ Feedback from customers & 4.23 & .627 & 1.705 & -.656 & 0.15 \\
\hline - $\quad$ Actions of competitors & 4.00 & .779 & 607 & -.704 & 0.19 \\
\hline - $\quad$ Changes in regulatory framework & 4.02 & 813 & 2.443 & -1.067 & 0.20 \\
\hline
\end{tabular}

\begin{tabular}{|c|c|c|c|c|c|}
\hline $\begin{array}{l}\text { Firm Performance- } \\
\text { Reputation }\end{array}$ & Mean & $\begin{array}{l}\text { S } \\
\text { D }\end{array}$ & KU & $\begin{array}{l}\mathbf{S} \\
\mathbf{K} \\
\end{array}$ & CV \\
\hline $\begin{array}{l}\text { We engage in transparent business } \\
\text { practices to enhance public trust }\end{array}$ & 4.44 & $\begin{array}{r}0 . \\
5 \\
9 \\
8\end{array}$ & $\begin{array}{r}2.90 \\
7\end{array}$ & $\begin{array}{r}- \\
1 . \\
05 \\
3\end{array}$ & 0.13 \\
\hline $\begin{array}{l}\text { Firm's reputation has not affected by } \\
\text { scandals. This has enhanced our } \\
\text { performance }\end{array}$ & 4.28 & $\begin{array}{r}0 . \\
9 \\
2 \\
1\end{array}$ & $\begin{array}{r}1.00 \\
9\end{array}$ & $\begin{array}{r}- \\
1 . \\
30 \\
9\end{array}$ & 0.22 \\
\hline $\begin{array}{l}\text { We involve ourselves in other } \\
\text { activities to ensure interests of all } \\
\text { stakeholders is taken care of. }\end{array}$ & 4.26 & $\begin{array}{r}0 . \\
6 \\
6 \\
9 \\
\end{array}$ & $\begin{array}{r}1.07 \\
9\end{array}$ & $\begin{array}{r}- \\
0 . \\
73 \\
1\end{array}$ & 0.16 \\
\hline $\begin{array}{l}\text { We engages in Corporate Social } \\
\text { responsibility (CSR) activities }\end{array}$ & 3.96 & $\begin{array}{c}0 . \\
6 \\
0 \\
9 \\
\end{array}$ & $\begin{array}{r}3.87 \\
2\end{array}$ & $\begin{array}{r}- \\
1 . \\
02 \\
6\end{array}$ & 0.15 \\
\hline $\begin{array}{l}\text { Claim issues are crucial to our } \\
\text { reputation }\end{array}$ & 4.49 & $\begin{array}{r}0 . \\
6 \\
5 \\
8 \\
\end{array}$ & $\begin{array}{r}2.32 \\
9\end{array}$ & $\begin{array}{r}- \\
1 . \\
33 \\
1\end{array}$ & 0.15 \\
\hline
\end{tabular}




\begin{tabular}{|c|c|c|c|c|c|}
\hline $\begin{array}{l}\text { Firm Performance- } \\
\text { Innovation }\end{array}$ & $\begin{array}{l}\mathbf{M} \\
\mathbf{e} \\
\mathbf{a} \\
\mathbf{n}\end{array}$ & $\begin{array}{l}\mathrm{S} \\
\mathbf{D}\end{array}$ & $\begin{array}{l}\mathbf{K} \\
\mathbf{U}\end{array}$ & $\begin{array}{l}\mathbf{S} \\
\mathbf{K}\end{array}$ & $\begin{array}{l}\mathbf{C} \\
\mathbf{V}\end{array}$ \\
\hline $\begin{array}{l}\text { Our critical processes are all } \\
\text { automated }\end{array}$ & 3.89 & .900 & -.038 & -.701 & 0.23 \\
\hline $\begin{array}{l}\text { Our operations computerized } \\
\text { and almost entirely paperless }\end{array}$ & 2.81 & 1.093 & -.801 & .144 & 0.39 \\
\hline $\begin{array}{l}\text { There are relevant } \\
\text { processes/programs to help us be } \\
\text { more competitive. }\end{array}$ & 3.54 & .825 & .779 & -.935 & 0.23 \\
\hline $\begin{array}{l}\text { The claims function is fully } \\
\text { automated from }\end{array}$ & 3.00 & 1.239 & -1.027 & .000 & 0.41 \\
\hline $\begin{array}{l}\text { Service provider functions } \\
\text { (claims adjustors, surveyors, } \\
\text { engineers, motor assessors) are } \\
\text { fully automated }\end{array}$ & 2.81 & 1.060 & -1.092 & -.065 & 0.38 \\
\hline $\begin{array}{l}\text { have analysis based programs for } \\
\text { improvement of efficiency in all } \\
\text { areas including social marketing }\end{array}$ & 3.29 & .890 & .186 & -.514 & 0.27 \\
\hline $\begin{array}{l}\text { All staff have technological tools } \\
\text { (personal computers and } \\
\text { internet) for efficiency in } \\
\text { performing their duties }\end{array}$ & 4.21 & .977 & 1.647 & -1.394 & 0.23 \\
\hline $\begin{array}{c}\text { Firm has necessary physical } \\
\text { infrastructure, knowledge and } \\
\text { skills, for service delivery to all } \\
\text { stakeholders. }\end{array}$ & 4.19 & .934 & 3.825 & -1.764 & 0.22 \\
\hline Mean Score & 3.91 & .838 & .936 & -.773 & 0.22 \\
\hline
\end{tabular}

$N=57: S D$ is standard deviation, $S K$ is skewness, $K U$ is kurtosis, $C V$ is coefficient of variation,

Source: Research Data 